\title{
Influence of "Snake-Bite" Effect on Investment Return Rate: Lithuanian Example
}

\author{
Assoc. Prof. Dr. Jekaterina Kartasova ${ }^{1}$ \\ Assoc. Prof. Dr. Ligita Gaspareniene ${ }^{2}$ \\ Assoc. Prof. Dr. Rita Remeikiene ${ }^{3}$ \\ 1, 2, 3 Mykolas Romeris University, Ateities str. 20, Vilnius \\ Email: jkartasova@mruni.eu; ligita.gaspareniene@mruni.eu; rita.remeikiene@mruni.eu
}

\section{Doi:10.5901/mjss.2014.v5n27p1769}

\begin{abstract}
Understanding of investors' behaviour starts from the investigation of its forming factors. Investment decisions depend on various of them and are often based on fundamental or technical analysis, so advocates of the concept of the rational economic man (Homo economicus) say that investors choose the company that maximizes their economic benefits. In fact, rational investor behaviour is the premise and basis of the majority of classical financial theories and models, but an investor's decision also reflects his/her subjective evaluations and the perceived risk levels and propensity to take risks are different (Kartašova, 2013). This paper examines one of the basic biases influencing investors' behaviour - snake-bite effect and provides empirical evidence of its impact on investors' decisions and, as a consequence, on investment rate or return. Authors assume that Lithaunian individual investors experienced "snake bite" effect become more risk averse and their behaviour reflects in their investment decisions made. The authors conducted Lithuanian individual investors behaviour in financial market pilot study based on their decisions made buying and selling stocks listed on NASDAQ OMX Stock Exchange. Taking into account the investors settled rules during the research the influence of "snake bite" effect to potential gains and losses was investigated. The results allow accepting the authors assumption and provide empirical evidence of the correlation between the investment rate of return and influence of "snake-bite" effect.
\end{abstract}

Keywords: Financial behaviour, irrational investor behaviour, "snake-bite" effect.

\section{Introduction}

In 1990, the new sphere, called financial behaviour, has emerged in academic journals, business issues and newspapers. In fact, the research of financial behaviour started more than 150 years ago. At first, in 1841, Mackay in the extraordinary popular article "Delusions and the Madness of Crowds" introduced the chronological timetable of various panics and schemes during the course of history. This work has revealed how human behaviour shows itself in financial markets. The supporter of financial behaviour Le Bon in his article "The Crowd: a Study of the Popular Mind" analyzes application of crowd psychology in such fields as behavioural finance, social psychology, sociology and history. Selden was one of the pioneers who researched psychology in stock markets in his book "Psychology of the Stock Market" in 1912. This scholar investigated investors' emotional and psychological power in finance markets. The three works mentioned above as well as many others appeared as the ground to apply the experience of psychology and sociology sciences in the area of finance.

The majority of the theories of economics and finance presume that investors behave rationally and always consider all information available in the decision making process (Jurevičienè and Ivanova, 2013). Economists are inclined to think that the market is stable and share prices follow the tendencies of economics. However, during recent years, increasing fluctuations in the market cannot be explained referring to the hypothesis of rationality. Considering current trends in the finance markets, it can be stated that even the smartest investors experience psychological deviations. Psychologists have established that any personal decision could be influenced by psychological, empirical and emotional subtleties (Baltussen, 2009).

The common investment mistakes are directly linked with human psychology and internal state at the moment of investment. Investors usually do not consider information accuracy which, in turn, causes the mistakes while buying or selling stock and reduces the profits that could have been earned. Over-confidence as well as the lack of confidence can impede rational decisions. 
An investor often gets disappointed; he loses self-confidence having experienced big losses. In other words, he feels "snake bite" effect after which he is just afraid to invest in risky securities. In 2000, after the burst of technology bubble, people lost a lot of money, and they have still refused to invest in technologies. This tendency - the "snake bite" effect - shows that investors are not able to understand that risk and benefit that is related to the finance sector is completely different in comparison with the one at the beginning of this century (Levišauskaite and Kartašova, 2012). All this can prevent hesitant people from using the opportunities of fast growth. The effect of "house money" is considered to be opposite to the one of "snake bite" - in the first case, investors feel that they can take higher risks on the income they earned from previous investment as it looks like this income had not been earned by the investors themselves but won in the gambling house. The investors, as inexperienced players, can be inclined to take too high risks just after the investment loss (Jurevičienè and Gausienè, 2010). Since these people do not treat the income as their personal, they are inclined to take unreasonable risks. The actions of this kind usually cause huge sudden losses. The scientists found that "house money" effect is typical for both professional and non-professional investors (Parisi, 2005).

The scientific problem: what effect does risk avoidance have on investment return?

The object of the research is investment return while avoiding risk under the influence of "snake bite" effect.

The aim of the research is to analyze individual investor's investment return linked with his irrational behaviour in Lithuanian finance market.

The following objectives were raised to fulfil the aim of the research:

1. To provide the theoretical essence of "snake bite" effect.

2. To estimate the investment return earned by the investor who has experienced "snake bite" effect.

3. To evaluate the possible profit that could have been earned by the investor without risk avoidance.

The methods of the research include the analysis of the scientific literature, the analysis of the scientific data and mathematical modelling. The data of the empirical research was processed using the "Microsoft Excel" software.

The main data sources are as follows: foreign and Lithuanian scientific articles, NASDAQ OMX BALTIC stock exchange statistical data.

Taking in mind the basic aim of the paper -understand the behaviour of an investor who has experienced "snake bite" effect while making investment decisions. The authors have carried out pilot research based on purchasing of the shares of joint-stock company "Vilniaus baldai" following NASDAQ OMX BALTIC stock exchange rates has been evaluated. The investor had set the rules which he followed while making the investment. "Snake bite" effect on possible profit or loss has been researched.

\section{Literature Review: "Snake Bite" Effect}

In this section, the types of improper investment behaviour will be reviewed and common investment mistakes as well as the ways to escape them will be analyzed.

Table 1. Investors behaviour influencing factors

\begin{tabular}{|l|l|}
\hline Effect & The essence of the effect \\
\hline Endowment effect & $\begin{array}{l}\text { reveals itself while investing is interpreted as a tendency to appreciate available items when several } \\
\text { identical ones are evaluated. This effect promotes investors not to take any actions and try not to } \\
\text { change the structure of their investment portfolio. }\end{array}$ \\
\hline Anchoring effect & $\begin{array}{l}\text { emerges when an investor is inclined to rely on the opinion of others, even if an advisor does not } \\
\text { possess any relevant competence or knowledge. However, his opinion has significant impact on } \\
\text { investor's decisions. }\end{array}$ \\
\hline House money effect & $\begin{array}{l}\text { income earned from investment is treated as the winning in the gambling house, so the investor is } \\
\text { more inclined to risk it. }\end{array}$ \\
\hline Cognitive dissonance effect & $\begin{array}{l}\text { emerges when a person, even knowing that his believes contradict facts, stick to them anyway. } \\
\text { Cognitive dissonance appears when personal actions differ from believes. }\end{array}$ \\
\hline Conformism effect & $\begin{array}{l}\text { when they adjust their behaviour to the norms in the particular group and so escape personal } \\
\text { responsibility for the mistakes. }\end{array}$ \\
\hline "Snake bite" effect & $\begin{array}{l}\text { emerges when having experienced huge losses, investors are afraid to take risks and avoid investing } \\
\text { in riskier securities. }\end{array}$ \\
\hline
\end{tabular}

Source: compiled by the authors 
The case of trying to break even effect, investors' behaviour opposes "snake bite" effect since they try to win back and invest in risky securities in order to cover huge losses. So, trying to solve the scientific problem of the paper, deeper analysis of "snake bite" effect and possible return or loss that an investor can have after experiencing this effect is provided below (Lehner, 2004).

The research includes four independent variables - believes, over-confidence, regrets and "snake bite" effect - which influence investor's decisions (see Fig. 1).

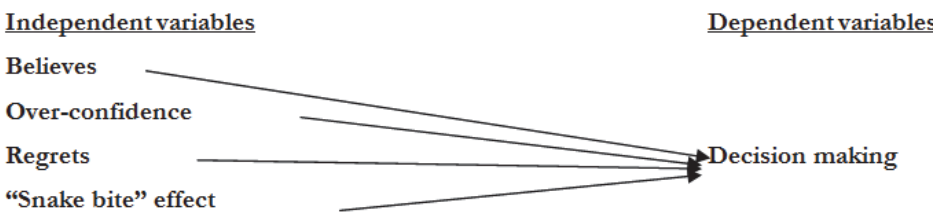

Figure 1. Basic decision making factors

Sourse: Prepared by authors

There is aninherent link between believes and investor's decisions (Baker, 2005). What is more, the link between confidence and over-confidence while making investment decisions can be seen: over-confidence does not allow assessing the risk properly and leads to knowledge overestimation which, in turn, causes making of improper decisions (Ricciardi, 2000). Regrets also have the impact on decision making - investors can take improper actions, for instance, sell securities when prices have dropped or buy them when prices have risen. The experiences like that can influence further investment decisions. The investors affected by "snake bite" usually become more careful and avoid risks (Chin, 2012).

\section{3. "Snake-bite" effect: empirical evidence}

Having looked over the statistical information available on the join-stock company "Vilniaus baldai" and having researched the tendencies of the share price changes, a non-professional individual investor decided to try investing in the shares in NASDAQ OMX BALTIC stock exchange (see Fig. 2) on in April 18, 2013.

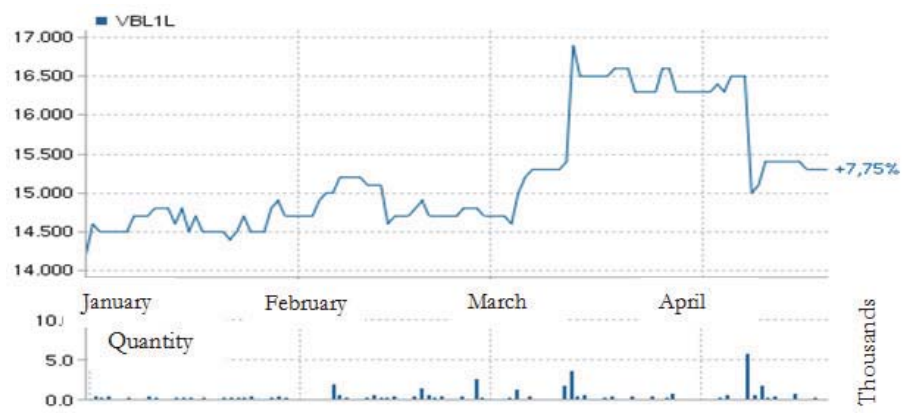

Figure 2. Share price changes from January 1, 2013 to April 18, 2013

Source: compiled by the authors with reference to the data of www.nasdaqomxbaltic.com

Consideration of the fact that price rises usually follow significant price drops promoted the investor to think that it was the best time for the investment. The investor set himself the following rules not to break regardless the emotions experienced in the cases of success or loss:

- $\quad$ to make purchases and sales at 9 a.m.;

- to purchase stock on Fridays and sell on Mondays;

- $\quad$ not to exceed the amount of 1000 EUR.

Having decided to invest 1000 EUR, the investor purchased 65 stocks of the joint-stock company "Vilniaus baldai" on April 22, 2013. The price per share on that day was 15.30 EUR, so the investor paid the total of 994.50 EUR. Share 
prices during the period of investment have been presented in Table 2 .

Table 2. Share prices during the period of April 19, 2013 - May 13, 2013 (EUR)

\begin{tabular}{|c|c|c|c|c|c|c|c|c|}
\hline 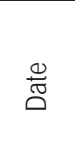 & 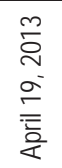 & 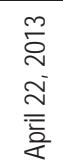 & 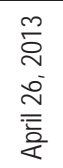 & $\begin{array}{l}m \\
\stackrel{D}{N} \\
\stackrel{D}{~} \\
\stackrel{\bar{z}}{0}\end{array}$ & 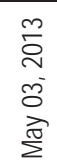 & 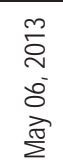 & $\begin{array}{l}m \\
\stackrel{0}{1} \\
0 \\
0 \\
0 \\
\stackrel{\pi}{2}\end{array}$ & 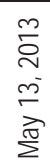 \\
\hline Price & 15.3 & 15.3 & 14.7 & 14.6 & 14.9 & 14.3 & 13.6 & 13.6 \\
\hline
\end{tabular}

Source: compiled by the authors with reference to the data of www.nasdaqomxbaltic.com

Following the rules he had set, the investor sold the shares on April 26, 2013 and experienced the loss of 39 EUR. This did not emerge as a desperate loss, and remained the hope that on Monday more shares will be bought on the available money, and the shares will be sold with a profit. Since share price dropped insignificantly, on April 29 the investor bought the same quantity of 65 shares. On Friday, the shares were sold and the first profit of 19.50 EUR was earned. On Monday, the investor bought 67 shares, but he was not satisfied with the investment since he followed the information on the price drops. The complete fiasco emerged on May 10, when the investor received 911.20 EUR with that week's loss of 46.90 EUR. Since the beginning of the investment, total loss of 83.30 EUR was experienced. The profit and loss was calculated excluding extra costs such as commission for purchase operationsand custodian fees.

Share purchase and custodian services were provided by the financial intermediary joint-stock company "SEB Bank Department of Securities and Finance Market Operations"; the fee for share purchase-sale by the internet in Baltic stock exchanges at that time was 0.25 per cent, i.e. 1000 EUR $\times 0.25 \%=2,50$ EUR.

Quarterly custodian fee was $0.02 \%$, i.e. 1000 EUR $\times 0.02 \%=0.20$ EUR. Since minimal quarterly custodian fee was $7 \mathrm{Lt}$ (2.03 EUR), the costs of monthly custodian services made $2.03 \mathrm{EUR} / 3$ months $=0.68 \mathrm{EUR}$.

Since every time the shares were bought for different price which did not exceed $1000 \mathrm{EUR}$, the fee for share purchase-sale by the internet did not exceed 2.50 EUR, and monthly custodian service did not exceed 0.68 EUR. The extra costs of this kind reduce profit and increase loss. Having estimated not only the initial loss but also the extra costs mentioned above, the investor decided to stop the investment and risk as a result of "snake bite" effect. The irrational behaviour as well as the decision to stop the investment were determined by personal emotions such as disappointment, sorrow, lack of confidence.

Thus, in this case, being hesitant, careful and probably possessing too little information and too many believes, the investor lost the opportunity to earn profits. If the investor had bought 67 shares on May 13 and sold them having waited longer than the following Friday, he could have earned higher profit than had been expected. Figure 3 shows that the strict rules set by the investor as well as the fear to take risk after experiencing the "snake bite" effect prevented the investor from profit lock.

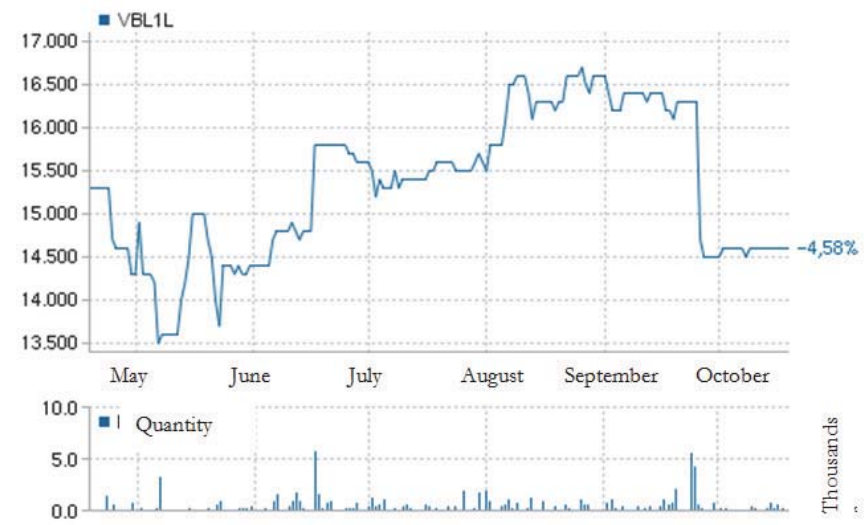

Figure 3. Share price changes during the period of April 19, 2013 - October 18, 2013

Source: Compiled by the authors with reference to the data of www.nasdaqomxbaltic.com 
At the point when the share price was 16.60 EUR, the investor would have earned the profit of 201 EUR. This leads to the conclusion that the people who have the fear to take risks lose the opportunity to earn higher profits.

\section{Conclusions}

The majority of economics and finance theories propose that investors behave rationally and always consider all information available in the decision making process. Considering current trends in the finance markets, it can be stated that even the smartest investors experience psychological deviations. Psychologists have established that any personal decision is inevitably influenced by psychological, empirical and emotional subtleties.

The research has revealed that a hesitant, careful and information lacking investor can lose the opportunity to earn profits. "Snake bite" effect, causing the fear to take risks, have the influence on investor's further decisions and behaviour, and prevents him from profit lock which, in turn, has the impact on profit margin and investment return.

\section{References}

Baker, M., P., Ruback, R. S. and Wurgler, J. (2005). Behavioral Corporate Finance: A Survey. [interactive]. [accessed on 20130706 ] through: <http://papers.ssrn.com/sol3/papers.cfm?abstract_id=602902>.

Baltussen, G. (2009). Behavioral Finance: an introduction. [interactive]. [accessed on 2013 07 06] through: $<$ http://papers.ssrn.com/sol3/papers.cfm?abstract_id=1488110>.

Chin, A. L. L. (2012). Psychological Biases and Investor Behaviour: Survey Evidence from Malaysian Stock Market. [interactive]. [accessed on 201307 01] through: <http://www.insightsociety.org/ojssea/index.php/ijssea/article/view/94/80>.

Jurevičienè, D. and Gausienè, E. (2010). Finansinès gyventoju elgsenos ypatumai. [interactive]. [accessed on 201308 15] through: $<$ <ttp://www.Ivb.It/primo_library/libweb/action/search.do?ct=Next+Page\&pag=nxt\&indx=11\&fctN=facet_tlevel\&dscnt=0\&rfnGrp=sh ow_only\&scp.scps=scope\%3A(LABT)\%2Cscope\%3A(PRM01)\%2Cscope\%3A(MAB05IST)\&fctV=online_resources\&frbg=\&tab=lo cal\&dstmp=1382272778504\&srt=rank\&vI(105951659UI0)=any\&ct=Next\%20Page\&vl(13517047UI1)=all_items\&mode=Basic\&du $m=t r u e \& i n d x=11 \& t b=t \& v \mid(1 U I S t a r t W i t h 0)=$ contains\&vl(freeText0)=elgsenos\%20finansai\&vid=LABT_VU1\&fn=search> .

Jurevičienè, D. and Ivanova, O. (2013). Behavioural finance: theory and survey. [interactive]. [accessed on 201308 15] through: $<$ http://www.mla.vgtu.tt/index.php/mla/article/view/mla.2013.08/pdf>.

Kartašova, J. (2013). Factors forming irrational Lithuanian individual investors' behaviour. [interactive]. [accessed on 201308 15] through:<http://www.Ivb.It/primo_library/libweb/action/search.do?ct=\&pag=\&indx=1\&fctN=facet_tlevel\&dscnt=0\&rfnGrp=show_onl y\&scp.scps=scope\%3A(LABT)\%2Cscope\%3A(PRM01)\%2Cscope\%3A(MAB05IST)\&fctV=online_resources\&frbg=\&tab=local\&ds tmp $=1382271204889 \& s r t=r a n k \& v|(105951659 U 10)=a n y \& c t=N e x t \% 20 P a g e \& v|(13517047 U I 1)=a l l \_$items\&mode=Basic\&dum=true \&indx=11\&tb=t\&vl(1UIStartWith0)=contains\&vl(freeText0)=investuotoj\%C5\%B3\%20elgsena\&vid=LABT_VU1\&fn=search> .

Lehner, O., M. (2004). A survey of behavioral finance. [interactive]. [accessed on 201307 06] through: $<$ http://papers.ssrn.com/sol3/papers.cfm?abstract_id=1669967>.

Levišauskaitè, K. and Kartašova, J. (2012). Investavimo patirties itaka individualiu investuotoju elgsenai ir ju priimamiems sprendimams finansu rinkoje. [interactive]. [accessed on 201308 15] through: <http://www.Ivb.It/primo_library/libweb/action/display.do? frbrVersion=3\&tabs=detailsTab\&ct=display\&fn=search\&doc=TLITLIJ.04 2012 1367187132772\&indx=11\&reclds=TLITLIJ.04 20 12 1367187132772\&recldxs=0\&elementld=0\&renderMode=poppedOut\&displayMode=full\&frbrVersion=3\&fctN=facet_tlevel\&dsc nt=0\&rfnGrp=show_only\&scp.scps=scope\%3A\%28LABT\%29\%2Cscope\%3A\%28PRM01\%29\%2Cscope\%3A\%28MABO5IST\%2 9\&fctV=online_resources\&frbg=\&tab=local\&dstmp=1382271062172\&srt=rank\&vl(105951659UI0)=any\&vl(13517047UI1)=all_item s\&mode=Basic\&dum=true\&tb=t\&vl(1UIStartWith0)=contains\&vl(freeText0)=investuotoj\%C5\%B3\%20elgsena\&vid=LABT_VU1 $>$.

Parisi, F. and Smith, V. (2005). The Law And Economics Of Irrational Behavior: an introduction. [interactive]. [accessed on 20130706 ] through: <http://papers.ssrn.com/sol3/papers.cfm?abstract_id=586649>.

Ricciardi, V. and Simon, H. K. (2000). What is Behavioral Finance? [interactive]. [accessed on 201307 06] through: $<$ http://papers.ssrn.com/sol3/papers.cfm?abstract_id=256754>. 